\title{
We Need to Show How Our Human Science Practice is a Relation of Pedagogy ${ }^{1}$
}

Max van Manen

University of Alberta

Requirement of a university based scholarship: (1) We need to show how our human science practice is a relation of pedagogy ... (2) Pedagogy as a human science is primarily a discursive practice. (Beekman, 1973, p. 27)

Human science is a dynamic relationship among people who talk and write... science is a discourse, a dialogue. (Beekman, 1983, p. 36)

"Why are you working again? Why don't you play with me? You are always working. Come on, let's play castle." As Michael tugs at my arm I know I have fallen short. Fallen short of that measure of pedagogy that is the topic of this paper. How can anyone spend time writing a book or paper about the notion of pedagogy and not fall short with one's own (or other people's) children. And yet, how can anyone write pedagogically about pedagogy if one does not stand pedagogically in life with one's own children?

I waffle, wanting to explain to Michael that it is midafternoon still, a workday for his father (would he really understand?); that I'm in my study at home writing for a friendship book for Ton Beekman. Michael should fondly remember Ton Beekman. I recall them playing in the backyard, imitating animal noises. I wonder, what would Ton Beekman say to Michael? Of course, I think I know. He would give himself happily and accompany Michael to the playroom where a big castle stands to be erected. But, then I also remember that Ton had no kids of his own. Did he have to live this tension of falling short? When Ton Beekman wrote "we need to show how our human science practice is a relation of pedagogy" was he likely interrupted by someone tugging at his arm? So here I am, in fear of my guilt, in face of the irony that one can experience the pedagogic presence of a child as an interruption of one's pedagogic work.

"He is laying it on, isn't he!" Michael's mother had overheard her son's cajoling, and her jest breaks in upon the situation. Like Michael's interruption, it effectively halts my textual labor. I get up from my chair, freed from one fear, the fear of writing. But now, can I give fully of myself? Or am I like the parent who is too busy to parent and now is about to serve the child his quotient of quality timeam I leaving my text in fear of pedagogy? 
No, I will not admit to that. That is after all the question I am trying to work out in this paper: What is the relation between pedagogy and theorizing about pedagogy? My suspicion is that for many educational theorists this relation is tenuous, or worse, their educational research and theorizing not only lacks pedagogy, it is severed also from a practical pedagogic orientation to children in their concrete lives. We are living in an age where our pedagogic commitment or interest in children is waning in favor of other concerns. Educational theorists exemplify their unresponsiveness to pedagogy in their avoidance of it. They would rather think of themselves as psychologists, sociologists, philosophers, ethnographers, critical theorists, and so forth, than as educators oriented to the world in a pedagogic way.

Few educational theorists have addressed the question of how to apply the measure of pedagogy to the standard of one's own work. To be unresponsive to pedagogy could be termed the half-life state of modern educational theory and research which has forgotten its original vocation: That all theory and research were meant to orient us to pedagogy in our relations with children. Andreas Flitner (1982) recounts how Langeveld once likened the products of much of educational research to a puzzle-each puzzle carries the same caption: "Can you find the child?" Where does all this theorizing and research still connect with the lifeworlds of children? Rather than teaching us to live our lives with children more fully, educational research so often seems to be cutting us off from the ordinary relation we adults have with children.

In modern forms of human science research in education, children may once again be recognizably present, however, their presence betrays a lack of true pedagogic commitment to them. The children may be there as objects of our human science interest in them-but they are not morally present in that they force us to reflect on how we should talk and act with them and how we should live by their side.

For example, the trendy surge of ethnographic research in education has produced numerous studies of children's lives (and of the educators who figure significantly in their lives): children in classrooms, on playgrounds, children in their neighborhoods, adolescents in shopping malls, teachers in various settings, and so forth. But what we are offered on the basis of these studies are texts of lives of children, teachers, administrators, and so forth that distance and estrange us from those lives rather than bringing these lives closer into the field of vision of our interest in children as teachers, parents, educational administrators, and so on. Why this fear of pedagogy? Researchers in education might object that it is one thing to try to understand the child's experience and quite another thing to do pedagogically something with this understanding. But one should 
wonder, is it ever possible to observe a child closely and to see the child's experience in a pure way? Outside of our relation to this child? Is it possible to describe a child, and his or her lifeworld, in a fashion that is disinterested, that lacks orientation? This would be hard to imagine. Every description always would seem to be animated by a certain interest. And this interest defines the relation in which I stand with respect to this child or these children. An adult's interest in a child may involve a kind of biographic seeing of the child's experience.

I see a child skipping rope in the street, and I pause and smile. I see a youthful bounce, the commanding rhythm of a rope-and perhaps a memory. I recognize this rhyme. Times do not change. When the child stops, I still feel the snap against my feet. Regret fills me. I wish I could revisit the old school playground. But then I come to myself. My childhood place is thousands of kilometers away. It is not likely I would see it again as I knew it. I turn away from that child and resume my walk. I saw a child, a rope, a game. Sight and sound collaborated to make me feel the rope against my feet. Then I saw regret, nostalgia. Then I went on my way. ${ }^{2}$

Did I see anything of this child's experience? Not likely. As mere passerby I do not even know this child. At best I recaptured something of my own childhood. But understanding a child's experience of skipping is not accomplished by reducing the child's experience to one's own. What would it involve to understand a child's experience of skipping? From a human science point of view we could try to explore the cultural experience of such play or we might attempt to describe the physiological quality of the skipping activity. We might try to understand how the body feels for the child, the quality of the rope, the rhythmic experience of different skipping songs and associated skills, the preferred sensation of the ground's surface, and very importantly the social significance of others in skipping games. If I were an ethnographer then I might ask the girl to tell me about skipping. I might discover that skipping is a game that has consequences for children's peer relations, their friendships, their communicative abilities, their sense of social stratification, and so forth. Similarly, a historian of children's games may see other aspects of the children's experiences, and so forth.

How might a teacher understand this child's experience of skipping? A teacher may have an eye for the phenomenological or ethnographic meaning dimensions of this child's experience. But a teacher's eye would first of all be trained by a pedagogic orientation.

The teacher sees Diane skipping rope. He sees much more than a passerby can see, for he has known her for more than a year. She skips away from the other children, and he wonders what it will take for Diane to 
become one of them. She is academically the best achiever of her class, but her achievements are not the product of some irrepressible raw intelligence. Diane earns her accomplishments with a grim fervor that saddens the teacher. She has an over-achieving mother who fosters ambitious goals. Diane's mother intends to have herself a gifted daughter. Diane complies. She earns her mother's favor, but at the price of childhood happiness, her teacher thinks. As he sees her skipping, he observes her tenseness and contrasts it with the relaxed skipping of the others. It is the same tenseness that betrays her anxiety with every assignment, every test. Diane marches rather than skips through the hoop of the rope.

The teacher also sees how Diane's eyes are turned to a half dozen girls who skip together with a big skipping rope. One of the girls returns her glance and gestures for Diane to come. Diane abruptly stops. The rope hits her feet and she turns toward the school door.

What does the teacher see? A lonely girl who can relate to classmates only by constantly measuring herself by competitive standards. If only she could develop some personal space, some room to grow and develop social interests just for herself, away from her mother. The teacher is hopeful, for in Diane's eyes he has spotted desire-a desire to be accepted by her classmates. ${ }^{3}$

An adult's understanding of a child's experience has something to do with the way this adult stands in the world. So we need to ask, what does it mean to be an educator and a human science researcher? Can we conveniently separate the two forms of life? I am not suggesting that something is inherently at fault with methodological perspectives derived from the various human sciences. Rather, there is a problem when a scientific research perspective is confused with pedagogic understanding. Is educational research educational when it fails to present itself in both form and content as an educational form of life? What happens to our voices when we are living the half-life? I have seen thoughtful educators involve themselves in graduate work and adopt some research perspective and language that strangely transforms them, leading them away from a pedagogic orientation toward an orientation that is typical of the scientific discipline in question. Now this educator, who once could offer such sensitive insights into the processes of teaching and parenting, speaks with an altered voice. It is the voice of the ethnographer, the critical theorist, the ethnomethodologist, the journalist, the phenomenologist, the critic, or the hermeneutic philosopher, and so forth-but one wonders: Where in all this research can we still hear the adult speak with a pedagogic voice? Where in this text is the connection with the everyday lifeworld which for this educator used to be invested with a pedagogic interest?

A researcher who sees him or herself as educator and who wants to arrive at better pedagogic understandings of questions concerning 
children's experiences-children reading, children at play, children learning in classrooms, children experiencing family break-up, children having difficulties, children experiencing loss, and so onneeds to inquire (reflect, speak, and write) in a manner that is both oriented and strong in a pedagogic sense. This means that, as we speak or write (produce text), we need to see that the textuality of our text is also a demonstration of the way we stand pedagogically in life. It is a sign of our preoccupation with a certain question or notion, a demonstration of the strength of our exclusive commitment to the pedagogy that animates our interest in text (speaking and writing) in the first place.

We live the half-life, unresponsive to pedagogy, when our scholarly activities are cut off from the pedagogic reason for this scholarship. In the domain of this half-life we see forms of theorizing that are severed from the moral life, the ordinary pedagogic practices, of which these forms of theorizing too are ultimately a part. There seems to exist much theory in education that lacks education. Educational theorists (of various cloth) have become unresponsive to their pedagogic responsibility to their readers and to the children with respect to whom their theories are constructed in the first place. Let me give some examples of this half-life.

\section{Who is Afraid of Pedagogy?}

Here is someone: Alice Miller. She is a German psychiatrist and author of For Your Own Good (1983), Prisoners of Childhood (1981), and Thou Shalt Not Be Aware (1984). Miller is an advocate of the notion of Black Pedagogy. ${ }^{4}$ She would put pedagogy out of business. Her many books are animated and keenly argued demonstrations of the subtle and not so subtle cruelties that parents, teachers, and educational practices willingly or unwillingly inflict on children. According to Miller most of us spend the larger part of our public and private lives trying to undo or put in perspective the scars, the pains, the obsessions, and the distortions that our so-called caretakers in childhood left us with.

Jean-Jacques Rousseau would of course agree with the accusations of Miller. And he should have known-I mean, of course, he should have known better! That is clear to anyone reading his confessions. He says, "The manner in which I had disposed of my children, however reasonable it had appeared to me, had not always left my heart at ease. While writing my Treatise on Education, I felt I had neglected duties with which it was not possible to dispense. Remorse at length became so strong that it almost forced from me a public confession of my fault at the beginning of my Emile" (Rousseau, 1980, pp. 572,573$)$. 
Rousseau immortalized himself with trailblazing texts on education. It is Rousseau who said that the heart often provides surer insight than reason: Heartless knowledge is dead knowledge. Knowledge without love, respect, and admiration for the being of a child cannot come to a full understanding of the child. Against the social forces of hypocrisy and selfish interests, Rousseau pitted belief in the virtue and goodness of human nature. And yet ... the children he fathered he relinquished to une maison pour des "enfants trouvés"-a home for foundlings. Strange thing. The man who, as theorists say, first saw the child as child did not know what his vision required of his body.

In life Rousseau failed as teacher, as governor of the sons of Monsieur de Mably. But Rousseau tried to reclaim his honor by showing that, theoretically at least, he knew what he could not embody. Thus appeared his justification: Projet pour l'education de M. de SainteMarie. It was his first scholarly paper. We have been writing scholarly papers ever since.

So where are we now? As followers of Rousseau, we see ourselves mirrored in scholarly activities. In the name of children, we gather at learned conferences where we give speeches, proclaim truths, and study or listen to those so much wiser than we are. For the sake of our children, we teach teachers, read and write articles, purchase and publish books. We feel humbled at the powerful surge of influence. In these texts, in these spaces, great teachers of teachers assemble to influence those who influence children. Incredible arrogance or pitiful drama?

Miller and Rousseau see all directive influence of parenting and teaching as forms of domination. One needs to deal with children as if they were one's friends rather than one's children, according to Miller. Her intentions are certainly honorable, showing more care for the lives of children than many child care professionals. One might even say that her polemic against pedagogy is deeply pedagogic. Child abuse knows many subtle forms and is much more prevalent than what one believes it to be. And yet, those who think that all pedagogy is oppression forget that to abolish pedagogy is to abolish the essential distinction between adults and children altogether. Unfortunately, or fortunately, children without are worse off than children with parents or teachers.

Who is Forgetful of Pedagogy?

The average modern European scholar-educator is. Earlier educational theorists such as Herman Nohl, Eduard Spranger, Theodor Litt, Erich Weniger, Wilhelm Flitner, and Otto Friedrich Bollnow, who founded their work especially on the notion of human science (Geisteswissenschaften) as developed by Wilhelm Dilthey, were 
poised to raise the question of the meaning of the notion of pedagogy. Their works are probing hermeneutic formulations of the meaning of pedagogy: the pedagogical relation (Nohl), pedagogical eros (Spranger), pedagogical influence (Litt), pedagogical praxis (Weniger), pedagogical reflection (Flitner), pedagogical atmosphere (Bollnow), and so on. ${ }^{5}$ However, it could be argued that some of the above theorists got entangled in exegetical discourse with a tradition which made a fresh questioning, a phenomenological beginning, a concrete interest in children too radical a challenge (too much hermeneutics and too little phenomenology?). Only a figure such as, perhaps, Martinus J. Langeveld succeeded in placing the question of the meaning of pedagogy in the lives of real children in a pedagogically addressable fashion. ${ }^{6}$ But among lesser contemporary Dutch and German scholars, Langeveld seems only to be remembered (with few exceptions) largely for what he supposedly failed to do.

\section{Who Misinterprets Pedagogy?}

Lee Shulman does. Past president (1985) of the American Education Research Association (AERA), Shulman, like many researchers, confuses pedagogy with the teaching process. Last year, Shulman, in his presidential AERA address, presented a well formulated speech on knowledge growth in teachers. ${ }^{7}$ In this speech, Shulman claimed that what is wrong with the theory and research of teacher education is the failure to notice the significance of what he calls the missing paradigm: the question of content. His critique of pedagogy turns into a critique of curriculum. He argues that educational research and teacher education has swung so far toward the study of mere pedagogy that it has forgotten all about content. With the overemphasis on the process of teaching, one has tended to forget that to teach is always to teach something: content.

Of course the same oversight is present in other areas: Reading theorists often forget that to read is always to read something meaningful to a particular child; evaluation theorists tend to forget that to evaluate is always to value specific human situations; and educational administrators are inclined to forget that to administer is always to minister to real children or specific settings serving real children. The irony is that Shulman finally is discovering the missing paradigm after everyone has already looted the thing. Back to the basics, core programs, course content revisions, and politically controversial system-wide tests of teacher knowledge of content areas all point to the fact that the missing paradigm was not missing from the action. So, we should not have our hopes up too high that Shulman has identified the real topos for effective pedagogy. Pedagogy is neither a question of process nor an issue of content. 
Many North American scholar-educators do. They will talk or write about anything faintly reasonable or absolutely absurd in relation to its association with the enterprise of educating real children, but not about the question of the nature of pedagogy. Yet, still, the word pedagogy has crept into recent North American literature dealing with curriculum, teaching, teacher education, and so forth. ${ }^{8}$ The term has been roughly equated with the act of teaching, instructional methodology, curriculum approach, or education in general. There has been little attempt to pose the question of the nature of pedagogy, to dialogue about the meaning of pedagogy in our everyday lives. The reason for this may be the elusiveness of the meaning of the notion of pedagogy. Where should we attempt to find the location or the space where pedagogy may be seen to reside? In the educator's acting? In the educational intention? In the theory or knowledge forms that teachers or parents use? In the effects that teachers have on children? Can pedagogy be observed? Can it be experienced? What does it mean to ask for the nature of pedagogy in this way?

\section{On the Unteachability of Pedagogy}

We may have to accept the possibility that the notion of pedagogy may be an unteachable, and that no scientific observation or conceptual formulation will lead to an unambiguous definition of pedagogy. But just because pedagogy is beyond the effort of teacher competence or parent skill training does not make it any less a desirable object for our understanding. So we may have to think of pedagogy, the essence of teaching, as unsuitable for teaching. I will outline three dialogic (that is to say, ironic) interpretations of the need to understand why and how pedagogy may be unteachable.

First, start with Plato; we must always start with Plato! There is a classic answer suggested in Plato's Meno. This is a starting point, because, in spite of Plato's apparent reservations about the adequacy of written text to represent life, his Dialogues are the great prodigy of the philosophic tradition. There is no other text that has so effectively penetrated into the lifeblood of philosophy and the human sciences. No other human science text has so dramatically resisted the polemic efforts to deal with it in a final and conclusive way. No other text has remained so fresh and untainted in spite of many hundreds of years of dogmatic exegesis and analytic assault. How can any teacher fail to marvel at this incredible textual power to teach those willing to read? I ask this because even a nonphilosophic reading of Plato can prompt questions so deep that it leaves one profoundly stirred. 
Socrates engages Meno on the question of the nature of virtue. Is virtue a form of knowledge and therefore teachable, or acquired by practice? Or is it granted by divine dispensation? As we know, the end of the Meno dialogue still ends in perplexity. Socrates retracts whatever conclusions seem warranted.

Meno meets Socrates in the street and strikes up a conversation: "Can you tell me, Socrates-can virtue be taught?" The reader of Plato's dialogue has come to expect Socrates' answer. He claims ignorance. There is nothing to tell about virtue in a propositional sense. Meno answers slyly, "But Socrates you are supposed to be so smart. You can't do better than that?" Meno asks Socrates for an expert opinion, but Socrates rejects this role. The question of virtue and teaching cannot be captured by polemical argument or by giving speeches. Socrates needs to establish a dialogical relation with Meno to open the question of the teachability of virtue in a teachable way. And just as Socrates needs to establish a dialogic relation with Meno, so Plato (or rather Plato's text) needs to establish a dialogic relation with the reader.

Dialogically constructed texts allow us to recognize our lives in the mimicry of stories and conversational anecdotes. Thus it allows for a certain space-a voice-which teaches by its textuality what the sheer content of the text only manages to make problematic. So I look in Plato's dialogues on the teachability of virtue for this space. In other words, when we read Plato on the topic of pedagogy, we are disappointed if we fail to recognize that the real understanding of virtue (or pedagogy) is not captured by definition or by way of a conclusive statement such as, "Yes (or No) virtue is a kind of knowledge." Socrates appears to waffle in the end. Yet the reader has gained something more important than a definition. He or she has had the experience of being oriented (turned around) to the notion of virtue in a way that is profoundly conclusive.

It is important to see this, that poetic texts such as Plato's dialogues practice a certain textuality; a dialogic textuality that asks for a mimetic reading. Dialogic text can teach indirectly what monologic text fails to achieve.

The first ironic interpretation was suggested by perhaps the most classic dialogic text. The second ironic interpretation of why we may have to think of pedagogy as unteachable is an approach taken by the most modern sort of text: postmodernism. Postmodernists such as Foucault, Barthes, Derrida, and Kristeva see the textuality of text as essentially dialogic. The postmodern position would say that pedagogy is not really anything. It is not something inside the text, as if words on a page could provide pedagogy to the reader, nor is pedagogy something outside the text, as if it were summoned by the text. Pedagogy, like textuality itself, ${ }^{9}$ is neither a this nor a that. 
Pedagogy is neither the theory we have of teaching, nor is it its application. We all know that theoretical scholarship in education does not vouch for pedagogic competence. Pedagogy does not reside in theory. But neither is pedagogy located in the application of theory. One may be an expert on translating learning theory into particular curriculum programs: However, it is doubtful if a certain curriculum (or learning theory application) could ever be sensitive to the way a particular child learns something specific.

Pedagogy is neither the intention nor the action. When a child complains that he or she is not understood or properly treated and loved, then no set of good intentions, aims, or curriculum objectives on the part of the parent or teacher will alter this fact. Regardless of the teacher's intention, the pedagogically important question is always, What is this situation or action like for the child? Pedagogy does not reside in a certain behavior. If it did, then all we would need to do would be to copy the relevant actions or behaviors. Pedagogy is not inherent in a certain action; rather, it resides in that which makes the action pedagogic in the first place.

Pedagogy is neither the body nor the heart. Pedagogy does not magically ensue from the corporeal-the fact that I am the biological parent or the in-loco-parentis teacher of this child. Nor is pedagogy secured by sheer love, as we know from the tragic lives of children who were loved to death.

So a postmodern perspective alerts us to the mistaken tendency to confuse pedagogy with text or its reference, with process or content, with its medium or its end. Pedagogy is neither one nor the other; rather it constantly and powerfully operates in between.

The third ironic interpretation of pedagogy's unteachability is derived from the lived sense of life itself. In the practice of living we must ask, "Don't we already know what pedagogy is?" The answer is paradoxical; we do and we don't. We do, because parenting (and teaching) truly is the oldest profession in the world. Child rearing is as intrinsic to human life as is feeding, clothing, caring, and sheltering. Pedagogy inheres in our phenomenological response to the child's natural helplessness. In spite of the historical atrocities human beings have inflicted on their offspring, we recognize that there is a natural need to do right with the young child. (Call it instinct, sentimentality, culture, motherhood, or paternity; call it whatever you like.)

It is the poverty of social science that it fails to see an obvious fact. The young child, by virtue of its very vulnerability, tends to bring out the best in grown-ups. The parent experiences the newly born as an appeal, as a transforming experience to do something: to hold the child, protect her, smile, and already worry perhaps if everything is 
all right. The first overwhelming sense a new parent experiences is often this ability of a natural responsiveness; response-ability-the unfolding of our pedagogic nature.

As new parents, before we have a chance to sit back and reflect on whether we can accept this child, the child has already made us act. And, luckily for humankind, this spontaneous needfulness to do the right thing is usually the right thing. As we reach to hold the child (rather than turn away and let it perish), we have already acted pedagogically. This is our practical "knowledge" of pedagogy. It is pretheoretic, prereflective. Yet, when living side by side with adults, children soon prompt increasingly reflective questions.

In other words, as soon as we gain a lived sense of the pedagogic quality of parenting and teaching, we start to question and doubt ourselves. Pedagogy is this questioning, this doubting. We wonder: Did I do the right thing? Why do some people teach or bring their children up in such a different manner? We are shocked when we see or hear how children are physically or psychologically abused. We also may notice in distress how many children are more subtly illtreated or abused. We see this all around us in shopping places, in public transportation locations, in the neighborhood, and on the street. We wonder how children experience being kept (abandoned?) for long hours in day care institutions. What should we do about this? What can I do about this?

Educational theory offers models for teaching, approaches to discipline, techniques for teacher effectiveness, methods for curriculum, management procedures for effective parenting, rationales for modern child care, and so on. And yet we suspect that it is not enough to apply some techniques, follow a program, or trust social policy. As Langeveld once said, something more fundamental to our being human is required. To be able to do something, you have to be something!

We know how George Bernard Shaw once satirized, "He who can does. He who cannot teaches." But, teachers always utter the well worn repartee: "He who cannot teach teaches teachers." I have often had the feeling that teachers have hinted at a stronger point than George Bernard Shaw. As if the task to parent and to teach children is not difficult enough! Shouldn't we shudder at an incredible arrogance and inevitable sophistry implied in the idea of teacher education? Who dares to elevate himself or herself to such exalted status?

Someday, someone is going to be brave enough to do a mischievous study. It will truly test the pedagogic worth of dominant educational perspectives and theories. It will examine the lives of the people who produce scholarly writings about education. It will study the pedagogical value of the personal lives of those with high reputations. 
This one abandoned his wife and children for the sake of an academic career in education. That one leaves two children in day care from eight to five in order to free up time to write about teaching kids. This one is so messed up at home that she no longer knows how to talk to her daughter who metes out her daily revenge. That one admits, with regret, that he cannot remember much of his children's childhoods (absentee fatherhood is a common illness among the greats of educational theory). This one needed to break out, to experiment with life, with sex. His child has a chance at so-called "quality time" with a part-time parent during summer vacations. That one (though childless) claims a fascination with researching children's lives, but is not able to risk a personal pedagogic relation with a child.

Each anecdote becomes a paradigm case of pedagogic parody. But why would it be that so many people who preoccupy themselves daily with profundities about educational theory themselves are so shockingly neglectful or incompetent? Does it mean that what we say about children finds no reverberation in lived life, that living with children is one thing and talking about how we are to live with them something else? What is the significance of theorizing and research and scholarly thought if it absolutely fails to connect with the bodily practices of everyday life? What does it mean to stand for something if it does not make a person stand out?

So the third ironic interpretation of the unteachability of pedagogy is to suggest that we need to listen (in a dialogic way) to pedagogy itself. Of course, no sooner have we caught a glimpse of our pedagogic being, than we are prompted to reflect questioningly on the way we live with children, as we should do. We need to act in the lives we live, side by side with our children, but then also wonder-always wonder whether we did it right_-so as to be able to act pedagogically tomorrow. But, you say, this is a strange notion. For what could a pedagogic relation or situation be? How and when do we act pedagogically? With these questions we seem to be back at square one. Or are we? I hope you get my point!

\section{On the Pedagogic Practice of Textuality}

In education, we often confuse what is possible with what is pedagogically desirable. For example, even if it were possible for many children to read by age four, that does not mean that children should be reading at that early age. The understanding and skill required to teach children to read early is not the understanding and skill required for knowing what is appropriate for this or that particular child. The first kind of knowledge may be the expertise of reading theorists; the second kind of knowledge is pedagogic. 
My point is that, no matter how challenging it may be to develop theories or models of learning, reading, doing mathematics, and so forth, no number of learning theories, teaching methods, or reading models will tell us what is appropriate for this child in this situation. That is the task of pedagogical theory. Pedagogical theory has to be theory of the unique, of the particular case. Theory of the unique starts with and from the single case, searches for the universal qualities, and returns to the single case. The educational theorist, as pedagogue, symbolically leaves the child-in reflective thought-to be with the child in a real way, to know what is appropriate for this child or these children, here and now.

A child's learning experience usually is astonishingly mercurial and transitional in terms of moods, emotions, energy, and feelings of relationship and selfhood. Those who absorb themselves in their children's experiences of learning to read, to write, to play music, or any kind of in or out of school activity whatsoever, are struck by the staggering variability of delight and rancor, difficulty and ease, confusion and clarity, risk and fear, abandon and stress, confidence and doubt, interest and boredom, perseverence and defeat, trust and resentment children experience as common everyday occurrences. Parents may know and understand this. Some teachers do.

But how many curriculum theorists or teaching specialists know this? How many teacher-educators know how a single child learns? Can classroom methodology be responsive if it does not understand the ups and downs of one child's experience? And what must we do? What knowledge must we pursue? What research texts must we produce that are sensitive to the peculiar question of the nature of pedagogy? To do research, to theorize, is to be involved in the consideration of text, the meaning of dialogic textuality and its promise for pedagogy - for pedagogical thinking and acting in the company of children.

To conclude, I see four conditions for a pedagogic textuality.

Our text needs to be oriented. Whatever approach we seek to develop, it always needs to be understood as an answer to the question of how an educator stands in life, how an educator needs to think about children, how an educator observes, listens, and relates to children, how an educator practices a form of speaking and writing that is pedagogically contagious. The idea of orientation may seem trivial. Isn't the very fact that we write about curriculum, teaching, or education not already a manifestation of pedagogic orientation? My charge is that few educators display an understanding of the need for orientation in a reflexive and ontological sense. To say that our text needs to be oriented in a pedagogic way is to require of our orientation to research and writing an awareness of the relation between text and textuality, content and form, speaking and acting. 
To be oriented as researchers or theorists means that we do not separate theory from life, the public from the private. We are not simply being pedagogues here and researchers there-we are researchers oriented to the world in a pedagogic way.

Our text needs to be strong. Whatever interest we develop in talking and thinking about children, teaching, or parenting, it always needs to aim for the strongest pedagogic interpretation of a certain phenomenon. As we try to gain clarity about a certain notion-let it be reading, writing, discipline, play, the child's experience of difficulty, responsibility, risk, wonder, or the teacher's sense of motivation, application, method, or planning-it always requires of us that we use our orientation as a resource for producing pedagogic understandings, interpretations, and formulations, and that we strengthen this resource in the very practice of this research or theorizing. ${ }^{10}$ It requires that we do not treat our orientation as just one approach among many (as if pedagogy were a relativistic praxis), but that we try to formulate a pedagogic understanding that is exclusive of other interests. As Nietzsche (1984) said about the art of reading (and writing), "every strong orientation is exclusive" (p. 164). A strong pedagogic orientation requires that one reads any situation in which an adult finds himself or herself with a child as a pedagogic situation, which is to say as an answer to the question of how we should be and act with children.

Our text needs to be rich. An educator who is oriented in a strong way to the world of real children develops a fascination with real life. The meanings of the lived sense of phenomena are not exhausted in their immediate experience. A rich description is concrete, exploring a phenomenon in all its ramifications. The educator, as author, aims to capture life experience (action or event) in anecdote or story, because the logic of story is precisely that it retrieves what is unique, particular, and irreplaceable. So, in textual terms, this translates into an interest in the anecdotal, story, narrative, or phenomenological description. The dialogic quality of these devices is obvious, for they engage us, involve us, and require a response from us.

Our text needs to be deep. Depth is what gives the notion to which we orient ourselves its meaning and its resistance to our fuller understanding. Or as Merleau-Ponty (1968) expressed it: "Depth is the means the things have to remain distinct, to remain things, while not being what I look at at present" (p. 219). As we struggle for meaning, as we struggle to overcome this resistance, a certain openness is required. And the measure of our openness which is needed to understand something is also a measure of its depthful nature. Rich descriptions, that explore the meaning structures beyond what is immediately experienced, gain a dimension of depth. Research and theorizing that simplifies life, without reminding us of its fundamental ambiguity and mystery, thereby distorts and shallows-out life, failing to reveal its depthful character and contours. 
Any text that may teach us something about our pedagogic nature is bound to aim for a certain hermeneutic: restoring a forgotten or broken wholeness by recollecting something lost, past, or eroded and by reconciling it in our experience of the present with a vision of what should be. This kind of text cannot be summarized. To present research by way of narrative text is not to present findings, but to do a reading (as a poet would) of a text that shows what it teaches. One must meet with it, go through it, encounter it, suffer it, consume it and, as well, be consumed by it.

In the work of writing and reading text we must always ask: How can we invent in the text a certain space, a perspective wherein the pedagogic voice which speaks for the child can let itself be heard? And, as we hear it speak, of course, it may be bitter, accusing, or cynical about our pretensions and about the way we are, or should be, with our children.

"Who is Ton Beekman?" asks Michael. We open a photo-album and I point out Beekman sitting at the picnic-table in the backyard. "Oh yes," says Michael, "I know him." "Shall we both write something for him?" I suggest. "All right . . but later," says Michael. "Now lel's build a castle and play with the castle people." And so we do. (Writing is for the nightlife.)

\section{Notes}

1. An earlier version of this paper was presented at the annual conference of the American Education Research Association, San Francisco, April 1986.

2. This is a parallel example of Beets' illustration of the nature of pedagogic observation. See: N. Beets. (1952, 1975). Verstandhouding en

Onderscheid. Meppel: Boom. Also see: M. van Manen. (1979). The phenomenology of pedagogic observation. The Canadian Journal for Studies in Education (CSSE). 4(1). The anecdote is taken from M. van Manen. (1986). The tone of teaching. Richmond Hill, ON: Scholastic-TAB Publications.

3. From: M. van Manen. (1986). The tone of teaching. Richmond Hill, ON: Scholastic-TAB Publications.

4. The term Schwarze Pädagogik (Black Pedagogy) was used by Katharina Rutschky, in a book by this title, to refer to the idea that all education is a form of oppression of children.

5. Unfortunately, the major works of these authors have not been translated into English. Recent discussions of the Geisteswissenschaftliche Pädagogik appears in Hintjes, J. (1981), Geesteswetenschappelijke Pedagogiek, Meppel: Boom; in Imelman, J.D. (Ed.), (1979), Filosofie van Opvoeding en Onderwijs, Groningen: Wolters, Noordhoff; and in Danner, H. (1979), Methoden geisteswissenschaftlicher Pädagogik, München, Basel: E. Reinhardt. Helmut Danner's book is being prepared for publication in English by Duquesne University Press (forthcoming, 1987). 
6. See his Beknopte Theoretische Pedagogiek, Groningen: Wolters (first published in 1944).

7. Published in the Researcher, Washington, DC: February 1986.

8. Witness, for example, the Presidential Address by David C. Berliner (at the 1986 American Education Research Association annual conference awards presentations) which was entitled "In Pursuit of the Expert Pedagogue."

9. See the clarifying discussion of postmodernism by Hugh J. Silverman "Postmodernism, Language, and Textuality," and "What is Textuality?" in Phenomenology + Pedagogy, 4(1) and 4(2).

10. For a thoughtful expression of the meaning of a "strong social actor" see A. Blum and P. McHugh. (1984). Self-reflection in the arts and sciences. Atlantic Highlands, NJ: Humanities Press. Also, in personal communication A. Blum's thinking has been stimulating for me.

\section{References}

Beekman, A.J. (1973). Veelvormige Werkelijkheid. Meppel: Boom.

Beekman, A.J. (1983). Human science as a dialogue with children. Phenomenology + Pedagogy, 1(1).

Blum, A., \& McHugh, P. (1984). Self-reflection in the arts and sciences. Atlantic Highlands, NJ: Humanities Press.

Merleau-Ponty, M. (1968). The visible and the invisible. Evanston: Northwestern University Press.

Nietzsche, F. (1984). Human, all too human. London: University of Nebraska Press.

Rousseau, J.J. The confessions, part II, book 12.

van Manen, M. (1986). The tone of teaching. Richmond Hill, ON:

Scholastic-TAB Publications. 